\title{
Morphology and seed protein profile for a new species of the genus Cleome L. (Cleomaceae) from Pakistan
}

\author{
Sana Riaz ${ }^{1}$, Rubina Abid ${ }^{1 *}$, Syed Abid Ali ${ }^{2}$, Iqra Munir ${ }^{2}$, Muhammad Qaiser ${ }^{1}$ \\ ${ }^{1}$ Department of Botany, University of Karachi, Karachi-75270, Pakistan \\ ${ }^{2} \mathrm{HEJ}$ Research Institute of Chemistry, International Centre for Chemical and Biological Sciences (ICCBS), University of \\ Karachi, Karachi-75270, Pakistan
}

\begin{abstract}
A new species of the genus Cleome L. from Pakistan is described and illustrated. The new species is described under the name C. karachiensis sp. nov. and compared with two closely related species i.e., Cleome brachycarpa and C. viscosa in terms of morphology, palynology, seed morphology and seed protein profile. A key to the species of genus Cleome L. from Pakistan is also provided.
\end{abstract}

Keywords: Cleomaceae, Cleome, Pakistan, species novum, seeds

\section{Introduction}

The genus Cleome L. was first described by Linnaeus (1753) with 8 species under the family Capparidaceae. Since then many workers have treated this genus under the family Capparidaceae (DE Candolle 1824, Bentham and Hooker 1862, Boissier 1867, Oliver 1868, Hooker 1875, Hedge and Lamond 1970, Jafri 1973). Pax (1891) divided the family Capparidaceae into two subfamilies viz. Capparoideae and Cleomoideae, and placed the genus under the subfamily Cleomoideae. Airy Shaw (1965) raised the status of Cleomoideae to the family level, Cleomaceae. Similarly, the APG IV system (2016) based on DNA studies also accepted Cleomaceae as an independent family.

The genus Cleome L. is the largest genus of the family Cleomaceae, with 250 species, distributed all over the world (Mabberley 2008). Jafri (1973) in his treatment of the family Capparidaceae for the Flora of Pakistan recognized 9 species of Cleome and one subspecies i.e., C. heratensis subsp. pakistanica Jafri. Later on, the status of subspecies $C$. heratensis subsp. pakistanica was raised to specific level on the basis of morphological differences i.e., habit, leaf, style and petal apex (Khatoon and Perveen 2003).

During a field survey of the vegetation of Karachi University Campus the authors observed a small population of plants resembling Cleome viscosa L. and C. brachycarpa Vahl. ex DC., which at first sight appears to be a miniature of $C$. viscosa. However, detailed studies showed that they were not only different from both species but also showed no similarity to any other known species of Cleome. So the species is reported here as a new addition to the genus Cleome. In order to confirm the authenticity of the new species whether it is a biological species or not, the new species has been compared with both the closely related species i.e., Cleome brachycarpa and C. viscosa using the following parameters: i) Pollen morphology ii) Seed morphology iii) Protein and peptide fingerprinting along with overall general morphology.

\section{Materials and methods}

\section{Study sites}

Herbarium specimens (KUH) along with fresh material collected from Karachi University campus and Hub River road, Karachi district were examined (On-line Suppl. Appendix I).

\section{Pollen morphology}

Pollen grains were collected from mature anthers. For light and scanning electron microscopy, pollen grains were prepared following the standard method of Erdtman (1952). Pollen grains were mounted in unstained glycerine jelly for

* Corresponding author, e-mail: rubinaku@yahoo.com 
light microscopy. For scanning electron microscopy, pollen material was directly mounted with capillary tubes on metallic stubs using double adhesive tape, dried at room temperature then gold plated in a sputtering chamber and observed under scanning electron microscope. The observations were based on 5-10 specimens of C. brachycarpa, C. viscosa, and the new taxon. Pollen size, shape, colpi length and tectum surface were observed. The terminologies used are in accordance with Erdtman (1952) and Hoen (2011).

\section{Leaf trichome and styles}

Leaves and styles of all the three taxa were studied under scanning electron microscope (JSM-6380 A). For scanning electron microscopy, mature dried $1 \mathrm{~cm}^{2}$ parts of leaves and full length styles were mounted on metallic stubs using double adhesive tape, then gold plated in a sputtering chamber for a period of 6 minutes and observed under scanning electron microscope. The terminology used is in accordance with Metcalfe and Chalk (1957).

\section{Seeds morphology}

Mature and healthy seeds of the three taxa were collected and studied under stereomicroscope (Nikon XN model) and scanning electron microscope (JSM-6380 A). For scanning electron microscopy, the mature dried seeds were mounted on metal stubs using double adhesive tape, then gold plated in a sputtering chamber for a period of 6 minutes and observed under scanning electron microscope. Seed characters like seed shape, colour and surface were studied. The terminology used is in accordance with Lawrence (1970), Radford et al. (1974) and Stearn (1983) with slight modifications.

\section{Protein analysis}

Crude seed extracts $(20 \mu \mathrm{g})$ of the three taxa were subjected to sodium dodecyl sulfate polyacrylamide gel electrophoresis (SDS-PAGE) analysis under dissociating and denaturing conditions $(\mathrm{pH} 8.8$ in the presence of SDS and $\beta$-mercaptoethanol) for protein and peptide fingerprinting. The proteins and peptides were separated in 14\% resolving and $5 \%$ stacking gels at $140 \mathrm{~V}$ for $1.5 \mathrm{~h}$. and at the end of electrophoresis the gel was stained with $0.2 \%$ Coomassie Brilliant Blue G-250. In addition to the SDS-PAGE, the same samples $(100 \mu \mathrm{g})$ were also subjected to reversed phase fast protein liquid chromatography (AKTA-design Amersham Biosciences, Buckinghamshire, UK) using a reversed phase FPLC column ( $\mu$ RPC C2/C18, ST 4.6/100; Amersham Biosciences, UK). The columns were equilibrated in $0.1 \%$ trifluoroacetic acid (TFA)- $\mathrm{H}_{2} \mathrm{O}$ (buffer-A) and eluted with a slight linear gradient ( $60 \% \mathrm{~B}$ in $20 \mathrm{~min}$.) of $100 \%$ acetonitrile containing $0.1 \%$ TFA (buffer-B). The flow rate was maintained at $1 \mathrm{~min} / \mathrm{ml}$ and the elution was observed at $280 \mathrm{~nm}$. Automated software UNICORN 5.0 (Amersham Biosciences, $\mathrm{UK}$ ) was used for data analysis.

\section{Results and discussion}

\section{Taxonomic treatment}

Cleome karachiensis S. Riaz, R. Abid and M. Qaiser sp. nov. (Fig. 1).

Annual herb, stem erect, soft, unbranched, 4-17 cm tall, glandular hairy, leaves alternate, petioled, palmately compound, 3-5 foliate, leaflets entire, obovate-oblanceolate, acute, base cuneate, 6-16 ×3-9 mm, capitate glandular, sto-
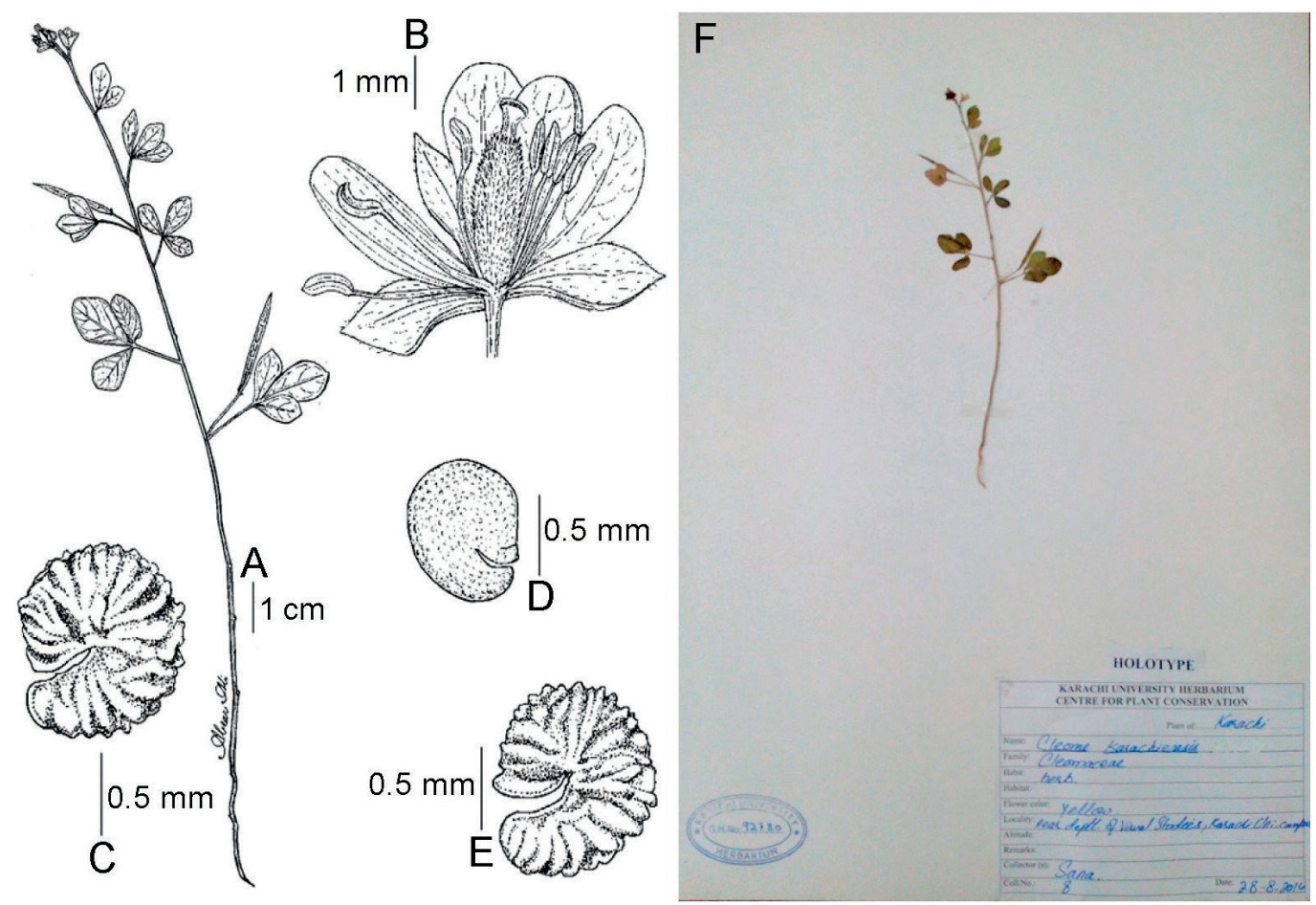

Fig. 1. Scheme of some characteristics of Cleome species. Cleome karachiensis S. Riaz, R. Abid and M. Qaiser: habit (A), flower (B), seed (C), type specimen (F); C. brachycarpa: seed (D), C. viscosa: seed (E). 
mata actinocytic. Flower yellow, complete, 5-8 $\mathrm{mm}$ across, pedicel $0.5-1.5 \mathrm{~cm}$; Sepals, 4 , green, dorsally glandular, oblong-obovate, acute, base truncate, $2-4 \times 0.5-1 \mathrm{~mm}$; petals 4 , yellow, oblanceolate, obtuse, cuneate, attenuate base, 2.5-6 $\times 1-2.5 \mathrm{~mm}$. Stamens 6-8. Ovary glandular; style $0.5-1 \mathrm{~mm}$ long; Capsule linear, many seeded, 10-29 × 1-2 mm (Fig. 1); Seeds light brown, myrtle green, retortiform with long groove, groove narrow towards the edges, surface concentrically ridged, foveate with appressedly colliculate, hilum lateral (On-line Suppl. Fig. 3).

Holotype: G-4 Pakistan, Karachi Dist.: near department of visual studies, Karachi University campus, 28-8-2014, Sana 8 (KUH) (Fig. 1F).

Paratype: G-4 Pakistan, Karachi Dist.: near department of visual studies, Karachi University campus, 28-8-2014, Sana $9(\mathrm{KUH})$; near department of visual studies, Karachi University campus, 4-9-2014, Sana \& Rubina Abid 61, 64, 65 (KUH); near department of visual studies, Karachi University campus, 16-8-2015, Sana 101, 102, 103 (KUH); near department of visual studies, Karachi University campus, 8-92015, Sana108 (KUH); Hub River road, 28-9-2017, Sana \& Rubina Abid 149 (KUH).

Etymology: The species is named after the city of Karachi, from which the type specimen was collected.

Distribution: Known only from the district of Karachi (Pakistan).

Ecology: The species grows in the sandy and dry plains in association with Cleome brachycarpa, C. viscosa, Prosopis juliflora, Calotropis procera, Abutilon spp., Peristrophe bicalyculata and various grasses.

Flowering period: August- October.

\section{C. viscosa L.}

Erect herb, 15-100 cm tall, branched or unbranched, hairy with glandular hairs. Leaves compound, alternate, tri-pentapalmate, petiole $5-43 \mathrm{~mm}$. Leaflets elliptic, broad elliptic, oblanceolate, lanceolate or obovate, acute or obtuse, base cuneate, attenuate, glandular, 14-32 × 3-17 mm. Flower complete, 7-15 mm across, yellow, pedicel 0.8-1.5 $\mathrm{cm}$. Sepals 4 , green, glandular, linear-oblong, oblong or oblong-lanceolate, acute, 4-6 × 1-2 mm. Petals 4, oblanceolate, oblong-lanceolate or oblong-elliptic, obtuse, base attenuate, $6-10 \times 1-3 \mathrm{~mm}$. Stamens 10-20, free, 3-10 mm long, unequal in length. Ovary glandular, 2.5-8.5 mm long, style persistent, 0.5-1 mm long, gynophore absent. Capsule linear, acute, base cuneate, glandular, striate, $37-80 \times 3 \mathrm{~mm}$. Seeds many, glabrous, rust brown or dark brown.

\section{C. brachycarpa Vahl. ex DC.}

Semi erect herb, 10-35 cm tall, branched from base, glandular. Leaves alternate, compound, tri-pentapalmate, glandular, petiole 2-30 mm. Leaflets elliptic, obovate, oblanceolate, oblong or orbicular, acute or obtuse, base cuneate, 6-20 $\times 2-8 \mathrm{~mm}$. Flower complete, $0.8-1.2 \mathrm{~cm}$ across, yellow, pedicellate. Sepals 4 , green, glandular, oblong, lanceolate, elliptic or oblong-elliptic, acute, $1.5-2.5 \mathrm{~mm}$ rarely up to $4 \times 0.5-2$
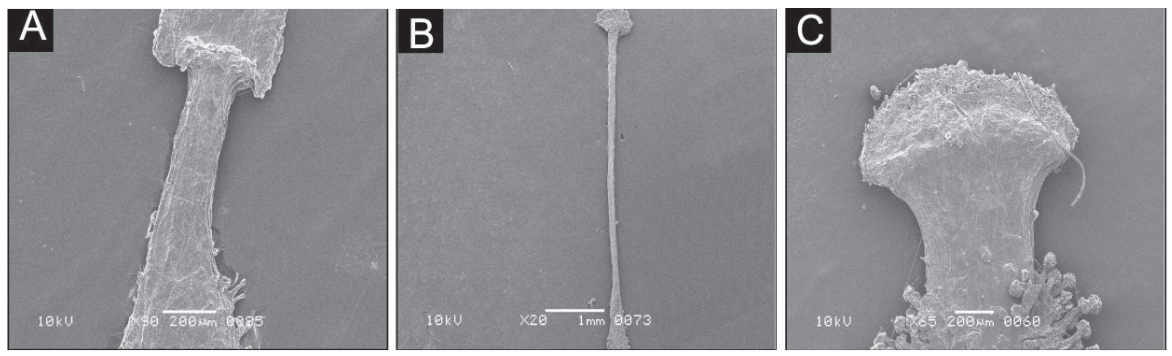

Fig. 2. Scaning electron micrographs of styles in Cleome species: Cleome karachiensis (A), C. brachycarpa (B), C. viscosa (C); scale bars: A, $C=200 \mu \mathrm{m} ; \mathrm{B}=1 \mathrm{~mm}$.
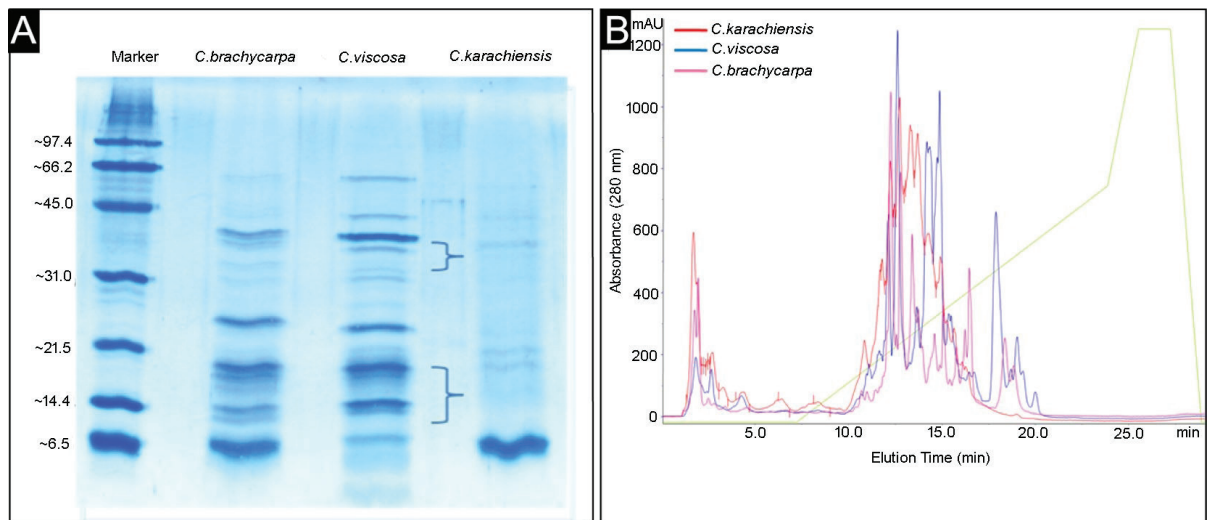

Fig. 3. Analysis of seed proteins of Cleome species. Protein and peptide finger printing using 14\% polyacrylamide gel electrophoresis under dissociating and denaturing conditions (A), protein liquid chromatography of the same samples on $\mu$ RPC C2/C18 column (B). 
$\mathrm{mm}$. Petals 4 , obovate or obovate-elliptic, acute, base cuneate, 3-7 $\times 1-3 \mathrm{~mm}$. Stamens 6, free, 2-6 mm long. Ovary glandular, 1-5 mm, ovules many, style persistent, $1-4.5 \mathrm{~mm}$, gynophore absent. Capsule 5-10 × 1.5-2 mm, oblong, glandular. Seeds many, glabrous, rust brown or maroon.

Cleome karachiensis sp. nov. shows close affinities with C. viscosa and C. brachycarpa in having 3-5 foliate, glandular leaves with acute apex and cuneate base, dorsally glandular sepals, yellow petals (Jafri 1973) and tricolporate pollen (Sanchez-Acebo 2005), non-angular seeds and a common protein band at $21.5 \mathrm{kDa}$. Besides the morphological affinities all the three species are growing simultaneously and occupying the same habitat. The new species is restricted in distribution, although other species are widely distributed. C. karachiensis sp. nov. seems to be the closest to C. viscosa in having capitate glandular trichomes on leaves (On-line Suppl. Fig. 1), obtuse petals, short style, subprolate pollen grains (On-line Suppl. Fig. 2), linear capsule and retortiform seeds (Fig. 1). On the other hand, C. viscosa remains distinct by having 10-20 stamens (Hedge and Lamond 1970), rust brown or dark brown seeds, concentrically ridged, foveate without appressedly colliculate seed surface and reticulaterugulate pollen tectum. The new species is also distinct from C. brachycarpa which is characterized by having peltate glandular trichomes on leaves (On-line Suppl. Fig. 1), acute petals, long style (Fig. 2), 6 stamens (Hedge and Lamond 1970, Jafri 1973), oblong capsule and elliptic-pyriform and ovoid seeds (Tab. 1), larger colpi, spinulose tectum (On-line Suppl. Fig. 2). However, the new species remains distinct from both of the allied species by having a soft herbaceous and 4-17 cm stem; 6-8 stamens (Fig. 1), shorter colpi (11.5-13.8 $\mu \mathrm{m}$ ), verrucate tectum (On-line Suppl. Fig. 2). The protein profile is also distinct from C. viscosa and C. brachycarpa in having only two protein bands between $14.4-21.5 \mathrm{kDa}$ zone and a single band between $31-45 \mathrm{kDa}$ zone. In contrast, in C. viscosa and C. brachycarpa there were 5 bands between 14.4$21.5 \mathrm{kDa}$ and 5 bands at 31-45 kDa zones (Fig. 3a). Similarly,
RP-FPLC data also support the findings of SDS-PAGE and all the three species can be distinguished from each other at the end of elution profile by protein fraction (retention time 5-20) at the peak pattern (Fig. 3b)

\section{Key to the species of Cleome L. from Pakistan}

1 Leaves simple. .2

Leaves compound ......................................................... 7

2 Undershrub, leaves scanty and very small. C. pakistanica

Herbs, leaves many and comparatively large ..................... 3

3 Fruit linear ........................................................................ 4

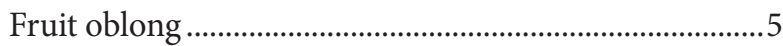

4 Stem and leaves glabrous, flowers yellow, $1 \mathrm{~cm}$ across, seeds hairy. C. oxypetala Stem and leaves hairy glandular, flowers pale white or pinkish, 3-4 $\mathrm{mm}$ across, seeds glabrous............ . scaposa

5 Stamens 6, fruits $50 \mathrm{~mm}$ long, seeds hairy....... . rupicola Stamens 4, fruits 12-30 mm long, seeds glabrous ..........6

6 Leaf base truncate or cordate, seeds angular

..C. dolichostyla

Leaf base obtuse or cuneate, seeds not angular

C. fimbriata

7 Petals linear-oblong, oblong, obovate, obovate-elliptic, stamens 6 ... . .8

Petals oblanceolate, oblong-lanceolate, oblong-elliptic, stamens 6-20. . .10

8 Stem semi erect, branched from base, flowers yellow...... .C. brachycarpa Stem erect, branched but not from base, flowers white or pinkish. ...9

9 Leaves 3 foliate, flowers $3-5 \mathrm{~mm}$ across, filaments $1-6 \mathrm{~mm}$

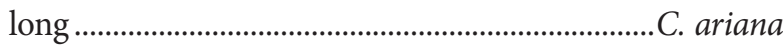
Leaves 5-7 foliate, flowers $25 \mathrm{~mm}$ across, filaments $25 \mathrm{~mm}$ long

C. spinosa

Tab. 1. Distinguishing characteristics of Cleome karachiensis sp. nov., Cleome viscosa and Cleome brachycarpa. Data in brackets indicate the minimum to maximum values.

\begin{tabular}{lccc}
\hline Characters & C. viscosa & C. karachiensis & C. brachycarpa \\
\hline Habit & Erect & Erect & Semi erect \\
Plant height $(\mathrm{cm})$ & $37.2 \pm 23.90$ & $10.76 \pm 3.91$ & $22.3 \pm 9.28$ \\
Branching & $(15-100)$ & $(4-17)$ & $(10-35)$ \\
Leaf trichomes & branched/unbranched & unbranched & branched from base \\
Petal apex & capitate glandular & capitate glandular & peltate glandular \\
No. of stamens & obtuse & obtuse & acute \\
Style length $(\mathrm{mm})$ & $10-20$ & $6-8$ & 6 \\
& $0.75 \pm 0.26$ & $0.75 \pm 0.26$ & $2.55 \pm 1.16$ \\
Capsule & $(0.5-1)$ & $(0.5-1)$ & $(1-4.5)$ \\
Seeds & linear & linear & oblong \\
Pollen shape & retortiform & retortiform & prorolate \\
Tectum & subprolate & subprolate & elliptic-pyriform or ovoid \\
Colpi length $(\mu \mathrm{m})$ & reticulate-rugulate & verrucate & spinulose \\
\hline
\end{tabular}


10 Stamens 6-8, fruit 10-29 mm long, seed surface appressedly colliculate C. karachiensis Stamens 10-20, fruit 37-80 mm long, seed surface not appressedly colliculate. C. viscosa

\section{References}

Airy Shaw, H. K., 1965: Diagnosis of new families, new names etc., for the seventh edition of Willis's "Dictionary". Kew Bulletin 18, 256.

APG (Angiosperm Phylogeny Group) IV. 2016: An update of the angiosperm phylogeny group for the orders and families of flowering plants. Botanical Journal of the Linnean Society $181,1-20$.

Bentham, G., Hooker, J. D., 1862: Genera plantarum ad exemplaria imprimis in herbariis kewensibus servata definite 1 . L Reeve \& Co., London.

Boissier, E., 1867: Flora Orientalis. Vol. 1, 410-416. Reimpression facsimilec A. Asher and Co., Geneva.

DE Candolle A. P., 1824: Prodromus systematics Naturalis regni vegetabilis, Vol. 1, 237-241. Sumptibus Sociorum Treuttel et Wurtz, Paris.

Erdtman G., 1952: Pollen morphology and plant taxonomy, Angiosperms, Chronica Botanica Co., Waltham.

Hedge I., Lamond J., 1970: Capparidaceae. In: Rechinger K. H. (ed.), Flora Iranica, Vol. 68, 13-30. Academische Druck-Uverlagsanstalt Graz Austria.

Hoen P., 2011: Glossary of pollen and spore terminology ( $2^{\text {nd }}$ ed.), Laboratory of Paleobotany and palynology, Utrecht, NL.

Hooker J.D., 1875: Flora of British India, Vol. 1, 168-170. L. Reeve \& Co. Ltd., London.

Jafri S.M.H., 1973: Capparidaceae. In: Nasir, E., Ali S. I. (eds.), Flora of Pakistan, Vol. 34, 20-32. The Herbarium, Dept. of Botany, University of Karachi, Karachi, Pakistan.

\section{Acknowledgements}

We are thankful to the Director, Centre for Plant Conservation for providing the herbarium facilities. Thanks are also due to Mr. Abrar Ali for illustration and photographic enhancement.

Khatoon S., Perveen A., 2003: Cleome pakistanica (Capparidaceae) - A new endemic species from Pakistan. Pakistan Journal of Botany 35, 145-146.

Lawrence G.H.M., 1970: Taxonomy of vascular plants. The Macmillan Company, Collier- Macmillan Canada, LTD., Toronto, Ontario, New York.

Linnaeus C., 1753: Species Plantarum, Vol. 2, 671-672. British Museum (Natural History) London.

Mabberley D.J., 2008: Mabberley’s Plant-book (3 ${ }^{\text {rd }}$ ed.), 194. Cambridge University Press, Cambridge.

Metcalfe C.R., Chalk, L., 1957: Anatomy of the Dicotyledons, II. Calerendon press, Oxford.

Oliver D., 1868: Flora of Tropical Africa, Vol. 1, 74-81. L. Reeve \& Co. Ltd., Ashford, Kent.

Pax., 1891: Capparidaceae. In: Engler, A., Prantl, K. (eds.), Pflanzenfam III. 2, 220.

Radford A. E., Dickison W.C., Massey J.R., Ritchie Bell C., 1974: Vascular Plants Systematics. Harper and Row, New York, Evanston, San Francisco, London.

Sanchez-Acebo, L., 2005: A phylogenetic study of the new world Cleome (Brassicaceae, Cleomoideae). Annals of the Missouri Botanical Garden 92, 179-201.

Stearn T.W., 1983: Botanical Latin ( $3^{\text {rd }}$ ed.), David \& Charles, UK. 